\title{
Salvage Regimens after Failure of Previous Helicobacter pylori Eradication Therapy: A Systematic Review and Meta-analysis
}

\author{
Hyo-Joon Yang ${ }^{1}$, Hye-Kyung Jung ${ }^{2}$, Seung Joo Kang ${ }^{3}$, Yong Chan Lee ${ }^{4}$, Seon-Young Park ${ }^{5}$, Cheol Min Shin ${ }^{6}$, Sung Eun Kim ${ }^{7}$, \\ Hyun Chul Lim ${ }^{8}$, Jie-Hyun Kim ${ }^{3}$, Su Youn Nam ${ }^{9,10}$, Woon Geon Shin ${ }^{11}$, Jae Myung Park ${ }^{12}$, Il Ju Choi ${ }^{13}$, Jae Gyu Kim ${ }^{14}$, Miyoung Choi ${ }^{15}$; \\ Korean College of Helicobacterand Upper Gastrointesinal Research \\ Division of Gastroenterology, Department of Internal Medicine and Gastrointestinal Cancer Center, Kangbuk Samsung Hospital, Sungkyunkwan \\ University School of Medicine, Department of Internal Medicine, Ewha Womans University School of Medicine ${ }^{2}$, Department of Internal Medicine, \\ Seoul National University Hospital Gangnam Center ${ }^{3}$, Department of Internal Medicine, Yonsei University College of Medicine $e^{4}$, Seoul, Department \\ of Internal Medicine, Chonnam National University Medical School ${ }^{5}$, Gwangju, Department of Internal Medicine, Seoul National University \\ Bundang Hospital ${ }^{6}$, Seongnam, Department of Internal Medicine, Kosin University College of Medicine ${ }^{7}$, Busan, Department of Internal Medicine, \\ Yongin Severance Hospital, Yonsei University College of Medicine ${ }^{8}$, Yongin, Department of Gastroenterology, Center for Gastric Cancer, Kyungpook \\ National University Hospital Chilgok Hospital ${ }^{9}$, Department of Gastroenterology, School of Medicine, Kyungpook National University ${ }^{10}$, Daegu, \\ Department of Internal Medicine, Hallym University College of Medicine ${ }^{11}$, Division of Gastroenterology and Hepatology, Department of Internal \\ Medicine, Seoul St. Mary's Hospital, The Catholic University of Korea ${ }^{12}$, Seoul, Center for Gastric Cancer, National Cancer Center ${ }^{13}$, Goyang, \\ Department of Internal Medicine, Chung-Ang University College of Medicine ${ }^{14}$, Division of Healthcare Technology Assessment Research, National \\ Evidence-based Healthcare Collaborating Agency ${ }^{15}$, Seoul, Korea
}

Background/Aims: As antibiotic resistance increases and new first-line therapies emerge, salvage therapies for Helicobacter pylori (H. pylori) eradication failures are becoming more common and complicated. This study aimed to systematically review overall salvage regimens after previous failure of $H$. pylori eradication.

Materials and Methods: A systematic review of randomized clinical trials evaluating salvage therapies after previous $H$. pylori eradication failure was performed. A meta-analysis was conducted when an adequate number of studies suitable for grouping was found. Results: Overall, 36 studies with 77 treatment arms were identified, and they were highly heterogeneous regarding previously failed regimens and salvage regimens under comparison. Bismuth quadruple therapy after failure of standard triple therapy showed a pooled intention-to-treat (ITT) eradication rate of 75.5\% (95\% CI, 71.6 79.1\%), and the rates were significantly higher with 14-day therapy than 7-day therapy by $9 \%(95 \%$ CI, 2 15\%). Levofloxacin triple therapy after failure of standard triple therapy demonstrated a pooled ITT eradication rate of 73.3\% (95\% CI, 68.4 77.3\%). In direct comparison, the two regimens were not significantly different in eradication rates. No study evaluated salvage regimens after the failure of bismuth or non-bismuth quadruple therapy.

Conclusions: The current studies regarding salvage regimens are highly heterogeneous. Bismuth quadruple therapy and levofloxacin triple therapy may be a reliable option after failure of standard triple therapy, but the regional profile of antibiotic resistance should be considered. Further studies are needed for salvage regimens after failure of non-bismuth or bismuth quadruple therapy. (Korean J Helicobacter Up Gastrointest Res 2021;21:59-71)

Key Words: Drug resistance, Bacterial; Helicobacter pylori; Meta-analysis; Salvage therapy; Systematic review

\section{INTRODUCTION}

Helicobacter pylori (H. pylori) infection is decreasing but still highly prevalent in Korea with a seroprevalence of 51\% in 2015 2016. ${ }^{1}$ Eradication of H. pylori is associated with prevention of peptic ulcer recurrence and regression of gastric mucosa-associated lymphoid tissue lymphoma. ${ }^{2}$ In addition,

Received: October 18, 2020 Revised: October 31, 2020 Accepted: November 2, 2020

Corresponding author: Hyo-Joon Yang

Division of Gastroenterology, Department of Internal Medicine and Gastrointestina Cancer Center, Kangbuk Samsung Hospital, Sungkyunkwan University School of Medicine, 29 Saemunan-ro, Jongno-gu, Seoul 03181, Korea

Tel: +82-2-2001-8330, Fax: +82-2-2001-8360, E-mail: hyojoonyang@gmail.com
H. pylori eradication can reduce the risk of metachronous recurrence in patients with early gastric cancer who underwent endoscopic resection and the risk of gastric cancer development in individuals with a family history of gastric cancer in first-degree relatives. ${ }^{3,4}$

The Korean guidelines published in 2013 recommended a 'standard' triple therapy of proton pump inhibitor (PPI), clarithromycin, and amoxicillin as a first-line regimen. ${ }^{2}$ However, with increased resistance to clarithromycin, ${ }^{5}$ the eradication rate of 7-day standard triple therapy is now only $70 \%{ }^{6}$ As a result, prescribing a salvage therapy after one or more failed eradication has become common in

Copyright $\odot 2021$ Korean College of Helicobacter and Upper Gastrointestinal Research

(a) The Korean Journal of Helicobacter and Upper Gastrointestinal Research is an Open-Access Journal. All articles are distributed under the terms of the Creative Commons Attribution Non-Commercial License (http:// creativecommons.org/licenses/by-nc/4.0) which permits unrestricted non-commercial use, distribution, and reproduction in any medium, provided the original work is properly cited. 
everyday practice. Because new regimens such as sequential or concomitant therapy have been suggested as new first-line treatment, choosing rescue therapy became more complicated.

In the Korean guideline, bismuth quadruple therapy was recommended after failure of first-line standard triple therapy. ${ }^{2}$ However, this guideline was not based on evidences from systematic reviews. More recent evidencebased guidelines recommend bismuth quadruple therapy or levofloxacin triple therapy as rescue regimens, but the detailed recommendations were slightly different with each other: Toronto guidelines recommended either bismuth quadruple therapy or levofloxacin triple therapy, American College of Gastroenterology guidelines favored bismuth quadruple therapy, and Maastricht V consensus report recommended either bismuth quadruple therapy or fluoroquinolone triple or quadruple therapy. ${ }^{7-9}$
Several systematic reviews evaluated salvage regimens for H. pylori infection with specific interest to levofloxacin-based therapy as a rescue regimen, ${ }^{10}$ comparison of levofloxacin triple therapy versus bismuth quadruple therapy, ${ }^{11}$ levofloxacin triple therapy as a third line regimen, ${ }^{12}$ refabutin-based rescue therapy, ${ }^{13}$ rescue regimens after failure of clarithromycin triple therapy, ${ }^{14}$ or overall second-line therapy. ${ }^{15}$ However, data are still insufficient regarding overall salvage regimens for persistent $H$. pylori infection.

Therefore, this study aimed to systematically review overall randomized controlled trials (RCTs) evaluating salvage regimens after previous failure of $H$. pylori eradication therapy and to conduct a meta-analysis evaluating successful eradication rate of each salvage regimen.

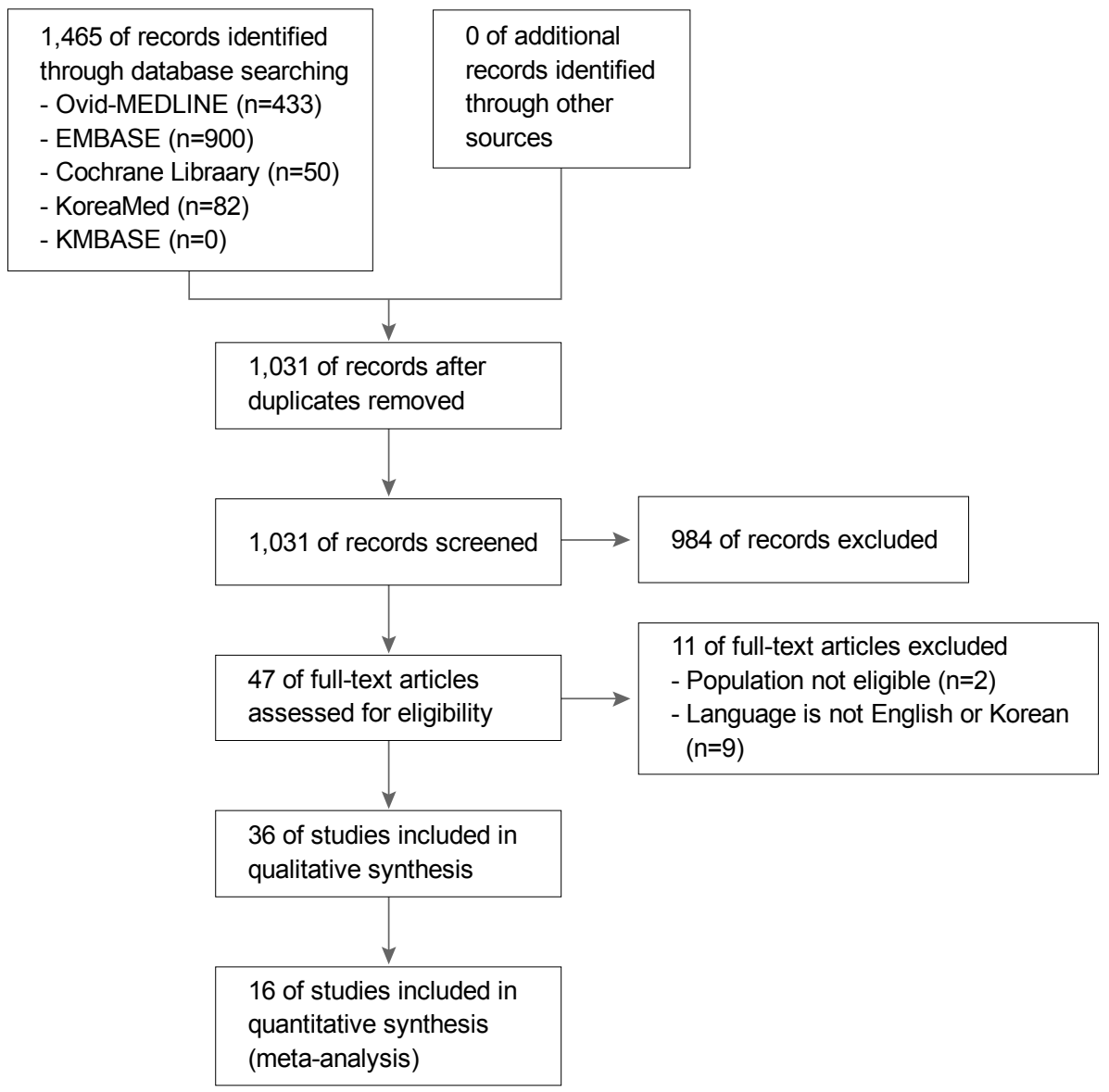

Fig. 1. Flow diagram showing the selection of the studies. 
Table 1. Characteristics of Studies Included in the Meta-analyses

\begin{tabular}{|c|c|c|c|c|c|c|}
\hline Study & Country & Previous regimen & Salvage regimen 1 & $\begin{array}{l}\text { ITT } \\
\text { erad- } \\
\text { ication } \\
\text { rate }\end{array}$ & Salvage regimen 2 & $\begin{array}{l}\text { ITT } \\
\text { erad- } \\
\text { ication } \\
\text { rate }\end{array}$ \\
\hline $\begin{array}{l}\text { Chuah et } \\
\text { al. }^{18} \\
(2012)\end{array}$ & Taiwan & $\begin{array}{l}\text { PPI bid, clarithromycin } 500 \mathrm{mg} \\
\text { bid, amoxicillin } 1 \mathrm{~g} \text { bid, dura- } \\
\text { tion not specified }\end{array}$ & $\begin{array}{l}\text { Esomeprazole } 40 \text { mg bid, bis- } \\
\text { muth } 300 \text { mg qid, tetracycline } \\
500 \text { mg qid, metronidazole } 250 \\
\text { mg qid, } 14 \text { days }\end{array}$ & $\begin{array}{c}86.0 \% \\
(43 / 50)\end{array}$ & $\begin{array}{l}\text { Esomeprazole } 40 \mathrm{mg} \text { bid, levo- } \\
\text { floxacin } 500 \mathrm{mg} \mathrm{qd} \text {, amoxicillin } \\
1 \mathrm{~g} \text { bid, } 14 \text { days }\end{array}$ & $\begin{array}{c}86.3 \% \\
(44 / 51)\end{array}$ \\
\hline $\begin{array}{l}\text { Karatapanis } \\
\text { et al. }^{19} \\
(2009)\end{array}$ & Greece & $\begin{array}{l}\text { Lansoprazole } 30 \mathrm{mg} \text { bid, clari- } \\
\text { thromycin } 500 \mathrm{mg} \text { bid, amox- } \\
\text { icillin } 1 \mathrm{~g} \text { bid, } 7 \sim 10 \text { days }\end{array}$ & $\begin{array}{l}\text { Lansoprazole } 30 \text { mg bid, bismuth } \\
120 \text { mg qid, tetracycline } 500 \mathrm{mg} \\
\text { qid, metronidazole } 500 \mathrm{mg} \text { tid, } \\
10 \text { days }\end{array}$ & $\begin{array}{c}78.9 \% \\
(30 / 38)\end{array}$ & $\begin{array}{l}\text { Lansoprazole } 30 \mathrm{mg} \text { bid, levo- } \\
\text { floxacin } 500 \mathrm{mg} \text { bid, amox- } \\
\text { icillin } 1 \mathrm{~g} \text { bid, } 10 \text { days }\end{array}$ & $\begin{array}{c}94.9 \% \\
(37 / 39)\end{array}$ \\
\hline $\begin{array}{l}\text { Kuo et al. } \\
\text { (2009) }\end{array}$ & Taiwan & $\begin{array}{l}\text { PPI bid, clarithromycin } 500 \mathrm{mg} \\
\text { bid, amoxicillin } 1 \mathrm{~g} \text { bid, dura- } \\
\text { tion not specified }\end{array}$ & $\begin{array}{l}\text { Esomeprazole } 40 \text { mg bid, bis- } \\
\text { muth } 120 \text { mg qid, tetracycline } \\
500 \text { mg qid, metronidazole } 250 \\
\text { mg qid, } 7 \text { days }\end{array}$ & $\begin{array}{l}63.9 \% \\
(53 / 83)\end{array}$ & $\begin{array}{l}\text { Esomeprazole } 40 \mathrm{mg} \text { bid, levo- } \\
\text { floxacin } 500 \mathrm{mg} \text { qd, amoxicillin } \\
1 \mathrm{~g} \text { bid, } 7 \text { days }\end{array}$ & $\begin{array}{c}69.9 \% \\
(58 / 83)\end{array}$ \\
\hline $\begin{array}{l}\text { Jung et al. } \\
(2008)\end{array}$ & Korea & $\begin{array}{l}\text { Omeprazole } 20 \mathrm{mg} \text { bid, clari- } \\
\text { thromycin } 500 \mathrm{mg} \text { bid, amox- } \\
\text { icillin } 1 \mathrm{~g} \text { bid, } 7 \text { days }\end{array}$ & $\begin{array}{l}\text { Pantoprazole } 20 \text { mg bid, bismuth } \\
600 \text { mg bid, tetracycline } 500 \mathrm{mg} \\
\text { qid, metronidazole } 500 \mathrm{mg} \text { tid, } \\
7 \text { days }\end{array}$ & $\begin{array}{c}48.9 \% \\
(22 / 45)\end{array}$ & $\begin{array}{l}\text { Pantoprazole } 20 \text { mg bid, levo- } \\
\text { floxacin } 300 \text { mg bid, smox- } \\
\text { icillin } 1 \mathrm{~g} \text { bid, } 7 \text { days }\end{array}$ & $\begin{array}{c}51.6 \% \\
(16 / 31)\end{array}$ \\
\hline $\begin{array}{l}\text { Jheng et al. }{ }^{22} \\
(2015)\end{array}$ & Taiwan & $\begin{array}{r}\text { PPI bid, clarithromycin } 500 \mathrm{mg} \\
\text { bid, amoxicillin } 1 \mathrm{~g} \text { bid, } 7 \text { days }\end{array}$ & $\begin{array}{l}\text { Rabeprazole } 20 \text { mg bid, bismuth } \\
120 \text { mg qid, tetracycline } 500 \mathrm{mg} \\
\text { qid, metronidazole } 250 \mathrm{mg} \text { qid, } \\
10 \text { days }\end{array}$ & $\begin{array}{c}92.1 \% \\
(58 / 63)\end{array}$ & $\begin{array}{l}\text { Rabeprazole } 20 \text { mg bid, amox- } \\
\text { icillin } 1 \text { g bid, tetracycline } 500 \\
\text { mg qid, metronidazole } 250 \mathrm{mg} \\
\text { qid, } 10 \text { days }\end{array}$ & $\begin{array}{c}90.2 \% \\
(55 / 61)\end{array}$ \\
\hline $\begin{array}{l}\text { Kuo et al. } \\
\text { (2013) }\end{array}$ & Taiwan & $\begin{array}{l}\text { Esomeprazole } 40 \text { mg bid, clari- } \\
\text { thromycin } 500 \text { mg bid, amox- } \\
\text { icillin } 1 \mathrm{~g} \text { bid, duration not } \\
\text { specified }\end{array}$ & $\begin{array}{l}\text { Esomeprazole } 40 \text { mg bid, bis- } \\
\text { muth } 300 \text { mg qid, tetracycline } \\
500 \text { mg qid, metronidazole } 500 \\
\text { mg qid, } 10 \text { days }\end{array}$ & $\begin{array}{c}79.7 \% \\
(59 / 74)\end{array}$ & $\begin{array}{l}\text { Esomeprazole } 40 \text { mg bid, bis- } \\
\text { muth } 300 \text { mg qid, tetracycline } \\
500 \text { mg qid, levofloxacin } 500 \\
\text { mg qd, } 10 \text { days }\end{array}$ & $\begin{array}{c}78.9 \% \\
(60 / 76)\end{array}$ \\
\hline $\begin{array}{l}\text { Moon et } \\
\text { al. }^{24} \\
(2013)\end{array}$ & Korea & $\begin{array}{l}\text { Lansoprazole, clarithromycin, } \\
\text { amoxicillin, dose not speci- } \\
\text { fied, } 7 \text { days }\end{array}$ & $\begin{array}{l}\text { Lansoprazole } 30 \mathrm{mg} \text { bid, bismuth } \\
120 \mathrm{mg} \text { qid, tetracycline } 500 \mathrm{mg} \\
\text { qid, metronidazole } 500 \mathrm{mg} \text { tid, } \\
7 \text { days }\end{array}$ & $\begin{array}{c}84.2 \% \\
(48 / 57)\end{array}$ & $\begin{array}{l}\text { Lansoprazole } 30 \mathrm{mg} \text { bid, metro- } \\
\text { nidazole } 500 \mathrm{mg} \text { tid, levo- } \\
\text { floxacin } 500 \mathrm{mg} \mathrm{qd}, 7 \text { days }\end{array}$ & $\begin{array}{c}67.9 \% \\
(38 / 56)\end{array}$ \\
\hline $\begin{array}{l}\text { Wu et al. } \\
\text { (2011) }\end{array}$ & Taiwan & $\begin{array}{l}\text { PPI bid, clarithromycin } 500 \mathrm{mg} \\
\text { bid, amoxicillin } 1 \mathrm{~g} \text { bid, dura- } \\
\text { tion not specified }\end{array}$ & $\begin{array}{l}\text { Esomeprazole } 40 \text { mg bid, bis- } \\
\text { muth } 120 \text { mg qid, tetracycline } \\
500 \text { mg qid, metronidazole } 250 \\
\text { mg qid, } 7 \text { days }\end{array}$ & $\begin{array}{r}80.6 \% \\
(50 / 62)\end{array}$ & $\begin{array}{l}\text { Esomeprazole } 40 \text { mg bid, bis- } \\
\text { muth } 120 \mathrm{mg} \text { qid, tetracycline } \\
500 \mathrm{mg} \text { qid, amoxicillin } 500 \mathrm{mg} \\
\text { qid, } 7 \text { days }\end{array}$ & $\begin{array}{c}94.7 \% \\
(36 / 38)\end{array}$ \\
\hline \multirow[t]{2}{*}{$\begin{array}{l}\text { Uygun et } \\
\text { al. }^{26} \\
(2008)\end{array}$} & \multirow[t]{2}{*}{ Turkey } & \multirow[t]{2}{*}{$\begin{array}{l}\text { Lansoprazole } 30 \mathrm{mg} \text { bid, clari- } \\
\text { thromycin } 500 \mathrm{mg} \text { bid, amox- } \\
\text { icillin } 1 \mathrm{~g} \text { bid, } 14 \text { days }\end{array}$} & \multirow[t]{2}{*}{$\begin{array}{l}\text { Three-group comparison } \\
\text { (Group 1) lansoprazole } 30 \mathrm{mg} \\
\text { bid, bismuth } 300 \mathrm{mg} \text { qid, tetra- } \\
\text { cycline } 500 \mathrm{mg} \text { qid, metronida- } \\
\text { zole } 500 \mathrm{mg} \text { bid, } 14 \text { days }\end{array}$} & $\begin{array}{c}78.0 \% \\
(78 / 100)\end{array}$ & $\begin{array}{l}\text { (Group 2) lansoprazole } 30 \mathrm{mg} \\
\text { bid, bismuth } 300 \text { mg qid, met- } \\
\text { ronidazole } 500 \text { mg bid, amox- } \\
\text { icillin } 1 \mathrm{~g} \text { bid, } 14 \text { days }\end{array}$ & $\begin{array}{c}68.0 \% \\
(68 / 100)\end{array}$ \\
\hline & & & & & $\begin{array}{l}\text { (Group 3) lansoprazole } 30 \mathrm{mg} \\
\text { bid, bismuth } 300 \mathrm{mg} \text { qid, tetra- } \\
\text { cycline } 500 \mathrm{mg} \text { qid, amoxicillin } \\
1 \mathrm{~g} \mathrm{bid,} 14 \text { days }\end{array}$ & $\begin{array}{c}75.0 \% \\
(75 / 100)\end{array}$ \\
\hline $\begin{array}{l}\text { Wu et al. } \\
\text { (2017) }\end{array}$ & Taiwan & $\begin{array}{l}\text { PPI bid, clarithromycin } 500 \mathrm{mg} \\
\text { bid, amoxicillin } 1 \mathrm{~g} \text { bid, dura- } \\
\text { tion not specified }\end{array}$ & $\begin{array}{l}\text { Rabeprazole } 20 \text { mg bid, levo- } \\
\text { floxacin } 500 \text { mg qd, amoxicillin } \\
1 \mathrm{~g} \mathrm{bid,} 10 \text { days }\end{array}$ & $\begin{array}{c}60.5 \% \\
(23 / 38)\end{array}$ & $\begin{array}{l}\text { Rabeprazole } 20 \text { mg bid, levo- } \\
\text { floxacin } 500 \text { mg qd, amoxicillin } \\
1 \mathrm{~g} \text { bid, bismuth } 120 \mathrm{mg} \text { qid, } \\
10 \text { days }\end{array}$ & $\begin{array}{c}80.0 \% \\
(28 / 35)\end{array}$ \\
\hline $\begin{array}{l}\text { Chuah et } \\
\text { al. }^{28} \\
(2016)\end{array}$ & Taiwan & $\begin{array}{l}\text { PPI bid, clarithromycin } 500 \mathrm{mg} \\
\text { bid, amoxicillin } 1 \mathrm{~g} \text { bid, dura- } \\
\text { tion not specified }\end{array}$ & $\begin{array}{l}\text { Esomeprazole } 40 \mathrm{mg} \text { bid, levo- } \\
\text { floxacin } 500 \mathrm{mg} \mathrm{qd} \text {, amoxicillin } \\
1 \mathrm{~g} \text { bid, } 10 \text { days }\end{array}$ & $\begin{array}{c}80.5 \% \\
(66 / 82)\end{array}$ & $\begin{array}{l}\text { Esomeprazole } 40 \mathrm{mg} \text { bid, levo- } \\
\text { floxacin } 500 \mathrm{mg} \text { qd, amoxicillin } \\
1 \mathrm{~g} \text { bid, metronidazole } 500 \mathrm{mg} \\
\text { tid, sequential } 10 \text { days }\end{array}$ & $\begin{array}{c}90.2 \% \\
(74 / 82)\end{array}$ \\
\hline $\begin{array}{l}\text { Chuah et } \\
\text { al. }^{29} \\
(2012)\end{array}$ & Taiwan & $\begin{array}{l}\text { PPI bid, clarithromycin } 500 \mathrm{mg} \\
\text { bid, amoxicillin } 1 \mathrm{~g} \text { bid, dura- } \\
\text { tion not specified }\end{array}$ & $\begin{array}{l}\text { Esomeprazole } 40 \mathrm{mg} \text { bid, levo- } \\
\text { floxacin } 500 \mathrm{mg} \text { qd, amoxicillin } \\
1 \mathrm{~g} \mathrm{bid}, 7 \text { days }\end{array}$ & $\begin{array}{l}78.1 \% \\
(50 / 64)\end{array}$ & $\begin{array}{l}\text { Esomeprazole } 40 \mathrm{mg} \text { bid, tetra- } \\
\text { cycline } 500 \mathrm{mg} \text { qid, amoxicillin } \\
1 \mathrm{~g} \text { bid, } 14 \text { days }\end{array}$ & $\begin{array}{c}75.0 \% \\
(48 / 64)\end{array}$ \\
\hline
\end{tabular}


Table 1. Continued

\begin{tabular}{|c|c|c|c|c|c|c|}
\hline Study & Country & Previous regimen & Salvage regimen 1 & $\begin{array}{l}\text { ITT } \\
\text { erad- } \\
\text { ication } \\
\text { rate }\end{array}$ & Salvage regimen 2 & $\begin{array}{l}\text { ITT } \\
\text { erad- } \\
\text { ication } \\
\text { rate }\end{array}$ \\
\hline $\begin{array}{c}\text { Hu et al. }{ }^{30} \\
(2011)\end{array}$ & Taiwan & $\begin{array}{l}\text { PPI bid, clarithromycin } 500 \mathrm{mg} \\
\text { bid, amoxicillin } 1 \mathrm{~g} \text { bid, dura- } \\
\text { tion not specified }\end{array}$ & $\begin{array}{l}\text { Esomeprazole } 40 \text { mg bid, levo- } \\
\text { floxacin } 500 \mathrm{mg} \text { qd, amoxicillin } \\
1 \mathrm{~g} \text { bid, } 7 \text { days }\end{array}$ & $\begin{array}{c}68.9 \% \\
(31 / 45)\end{array}$ & $\begin{array}{l}\text { Esomeprazole } 40 \mathrm{mg} \text { bid, metro- } \\
\text { nidazole } 250 \mathrm{mg} \text { qid, amox- } \\
\text { icillin } 1 \mathrm{~g} \text { bid, } 14 \text { days }\end{array}$ & $\begin{array}{c}84.4 \% \\
(38 / 45)\end{array}$ \\
\hline $\begin{array}{l}\text { Chung et } \\
\text { al. }^{49} \\
(2011)\end{array}$ & Korea & $\begin{array}{l}\text { Lansoprazole, clarithromycin, } \\
\text { amoxicillin, dose not speci- } \\
\text { fied, duration not specified }\end{array}$ & $\begin{array}{l}\text { Pantoprazole } 40 \text { mg bid, bismuth } \\
300 \text { mg bid, tetracycline } 500 \mathrm{mg} \\
\text { qid, metronidazole } 500 \mathrm{mg} \text { tid, } \\
7 \text { days }\end{array}$ & $\begin{array}{c}81.6 \% \\
(80 / 98)\end{array}$ & $\begin{array}{l}\text { Pantoprazole } 40 \text { mg bid, bis- } \\
\text { muth } 300 \text { mg bid, tetracycline } \\
500 \text { mg qid, metronidazole } 500 \\
\text { mg tid, } 14 \text { days }\end{array}$ & $\begin{array}{c}85.1 \% \\
(86 / 101)\end{array}$ \\
\hline $\begin{array}{c}\text { Lee et al. }{ }^{50} \\
(2010)\end{array}$ & Korea & $\begin{array}{l}\text { PPI bid, clarithromycin } 500 \mathrm{mg} \\
\text { bid, amoxicillin } 1 \mathrm{~g} \text { bid, dura- } \\
\text { tion not specified }\end{array}$ & $\begin{array}{l}\text { Esomeprazole } 20 \text { mg bid, bis- } \\
\text { muth } 300 \text { mg qid, tetracycline } \\
500 \text { mg qid, metronidazole } 500 \\
\text { mg tid, } 7 \text { days }\end{array}$ & $\begin{array}{c}64.3 \% \\
(72 / 112)\end{array}$ & $\begin{array}{l}\text { Esomeprazole } 20 \text { mg bid, bis- } \\
\text { muth } 300 \text { mg qid, tetracycline } \\
500 \text { mg qid, metronidazole } 500 \\
\text { mg tid, } 14 \text { days }\end{array}$ & $\begin{array}{c}82.6 \% \\
(95 / 115)\end{array}$ \\
\hline $\begin{array}{l}\text { Yoon et al. } \\
(2012)\end{array}$ & Korea & $\begin{array}{l}\text { PPI bid, clarithromycin } 500 \mathrm{mg} \\
\text { bid, amoxicillin } 1 \mathrm{~g} \text { bid, dura- } \\
\text { tion not specified }\end{array}$ & $\begin{array}{l}\text { Pantoprazole } 40 \text { mg bid, bismuth } \\
300 \text { mg bid, tetracycline } 500 \mathrm{mg} \\
\text { qid, metronidazole } 500 \mathrm{mg} \text { tid, } \\
7 \text { days }\end{array}$ & $\begin{array}{c}83.5 \% \\
(71 / 85)\end{array}$ & $\begin{array}{l}\text { Pantoprazole } 40 \text { mg bid, bis- } \\
\text { muth } 300 \text { mg bid, tetracycline } \\
500 \text { mg qid, metronidazole } 500 \\
\text { mg tid, } 14 \text { days }\end{array}$ & $\begin{array}{c}85.7 \% \\
(72 / 84)\end{array}$ \\
\hline
\end{tabular}

ITT, intention to treat; bid, twice a day; qid, four times a day; qd, once a day; tid, three times a day; PPI, proton pump inhibitor.

\section{MATERIALS AND METHODS}

\section{Literature search and selection}

A systematic bibliographic search was conducted in Ovid-MEDLINE, EMBASE, Cochrane Library, KoreaMed, and KMBASE. Search strategies were constructed using combinations of keywords as follows: (Helicobacter pylori OR Helicobacter infections OR H. pylori infection) AND (failure OR retreatment OR second OR salvage OR nonresponse) AND (eradication). References cited in the relevant articles and reviews were also checked for potential eligibility. Two authors (H.J.Y. and W.G.S.) independently reviewed the search outcomes and selected studies, and disagreements were resolved by discussion between the two authors. Inclusion criteria were 1) a RCT as the study design; 2) adult participants with previous failure of $H$. pylori eradication treatment as the study population; 3) two or more salvage treatment regimens containing at least one antibiotics plus PPI with different antibiotics, duration, or PPIs as intervention and comparator; 4) a successful eradiation rate as the outcome; 5) published between 2008 and 2018; and 6) written in English or Korean. Exclusion criteria were 1) nonrandomized or observational studies; 2) studies that included children or adolescents; 3) studies comparing agents such as probiotics or adjuvants other than antibiotics or PPI; 4) studies with no eradiation rates reported; 5) duplicated publication; 6) unable to obtain full text; and 7) expert opinion, review, and guidelines. This review was conducted in accordance with Preferred Reporting Items for Systemic Reviews and Meta-Analysis (PRISMA) statements. ${ }^{16}$

\section{Data extraction}

Data were extracted using a pre-specified data extraction table by two independent authors. Variables $\mathrm{ex}^{-}$ tracted were as follows: year of publication, country, number of patients overall and in each arm, mean age of patients, gender, previous treatment regimens including treatment duration and specific types and doses of antibiotics and PPI, duration of treatment, PPI type, dose, and schedule, antibiotics dose and schedule, timing of test to confirm eradication, successful eradiate rates by intention-to-treat (ITT) and per-protocol (PP) analyses.

\section{Risk of bias in individual studies}

The risk of bias in included studies were evaluated using the risk of bias (RoB) tool developed by Cochrane 
collaboration. ${ }^{17}$ The criteria was consisted of randomization, allocation concealment, blinding of participants and personnel, blinding of outcome assessment, incomplete outcome data, and selective outcome reporting, and other bias. Each criterion was recorded as low risk, high risk, or unclear. Two authors independently evaluated, and any discordance was resolved by consensus.

\section{Statistical analysis}

A meta-analysis was conducted when there were at least three studies reporting eradication rates of a treatment regimen or comparisons suitable for grouping. The pooled eradication rates and 95\% CIs of a single salvage regimen were estimated both for ITT and PP analyses. Subgroup analyses were conducted to evaluate whether the eradication rate was different according to the treatment duration of a salvage regimen. The risk difference (RD) and 95\% CI were calculated to compare eradication regimens using Review Manager (RevMan, version 5.3.5; Cochrane Collaboration, Copenhagen, Denmark). The heterogeneity of the studies was assessed using $I^{2}$ statistics. The publication bias was planned but not evaluated because there was no comparison with 10 or more studies.

\section{RESULTS}

\section{Study identification and selection}

A flow diagram of how relevant studies were selected was presented in Fig. 1. The original database search retrieved 1,465 articles. Among them, 434 articles were duplicated, and 984 studies were excluded by the initial screening by reviewing title and abstract, leaving $47 \mathrm{pa}-$ pers for the full text review. The articles were further $\mathrm{ex}^{-}$ cluded because study population were not eligible $(n=2)$ or language was not English or Korean ( $\mathrm{n}=9)$. As a results, we selected 36 RCTs (with 77 treatment arms) that compared two or more regimens, treatment durations, or PPIs in salvage therapy after at least one failure of previous $H$. pylori eradication for systematic review. ${ }^{18-53}$

\section{Characteristics of studies}

Among the 36 RCTs, 24 studies compared second-line regimens, ${ }^{18-41}$ five studies compared third-line regimens, ${ }^{42-46}$ five studies compared different durations of a salvage regimen, ${ }^{47-51}$ and two studies compared PPIs in a salvage regi-

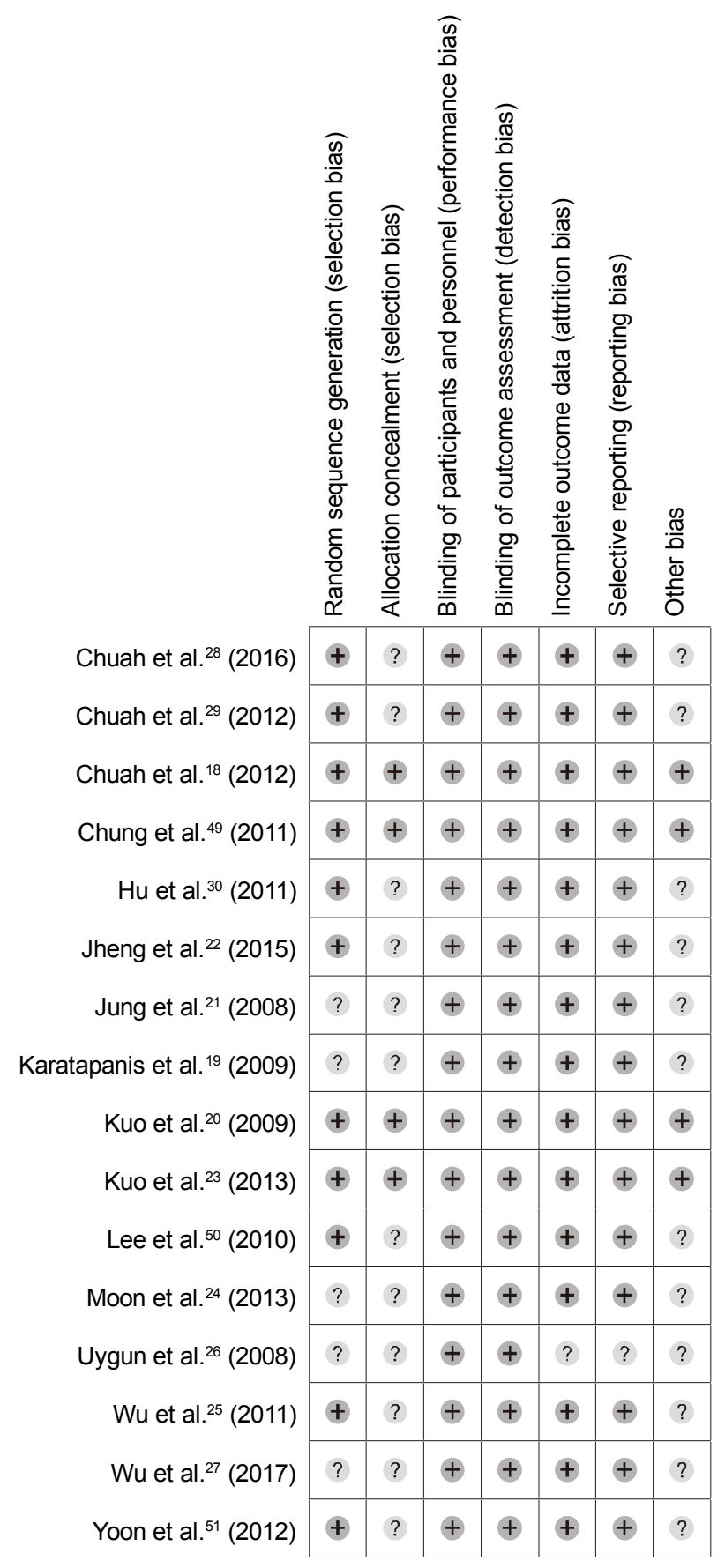

Fig. 2. Risk of bias of studies included in the meta-analyses. 
men (Supplementary Table 1). ${ }^{52,53}$ These studies were highly heterogeneous with respect to previous failed regimens and salvage regimens under comparison. Of the 24 second-line studies, ${ }^{18-41} 15$ studies included patients who failed standard triple therapy. ${ }^{18-32}$ There was no study that compared salvage regimens after failure of first-line non-bismuth quadruple therapy (sequential therapy or concomitant therapy), or bismuth quadruple therapy. After failure of standard triple therapy, bismuth quadruple therapy (PPI, bismuth, tetracycline, and metronidazole) was evaluated in nine trials, ${ }^{18-26}$ and levofloxacin triple therapy (PPI, levofloxacin, and amoxicillin) was in eight trials: ${ }^{18-21,27-30}$ four of them directly compared the two regimens. ${ }^{18-21}$ The other regimens were evaluated only in one or two studies. No study for third-line treatment evaluated salvage regimens after failure of second-line bismuth quadruple therapy following first-line standard triple or non-bismuth quadruple therapy. Each third-line salvage regimen was evaluated only in one or two studies. Among the five studies compared different treatment durations of a salvage therapy, ${ }^{47-51}$ three studies compared 7-day versus 14-day bismuth quadruple therapy after failure of first-line standard triple therapy. ${ }^{49-51}$

Consequently, a total of 16 RCTs were included in the following four meta-analyses (Table 1): 1) pooled eradication rate of bismuth quadruple therapy after failure of first-line standard triple therapy $(n=9) ; ;^{18-26}$ 2) 7-day versus 14-day bismuth quadruple therapy after failure of first-line standard triple therapy $\left.(n=3){ }^{49-51} 3\right)$ pooled eradication rate of levo-

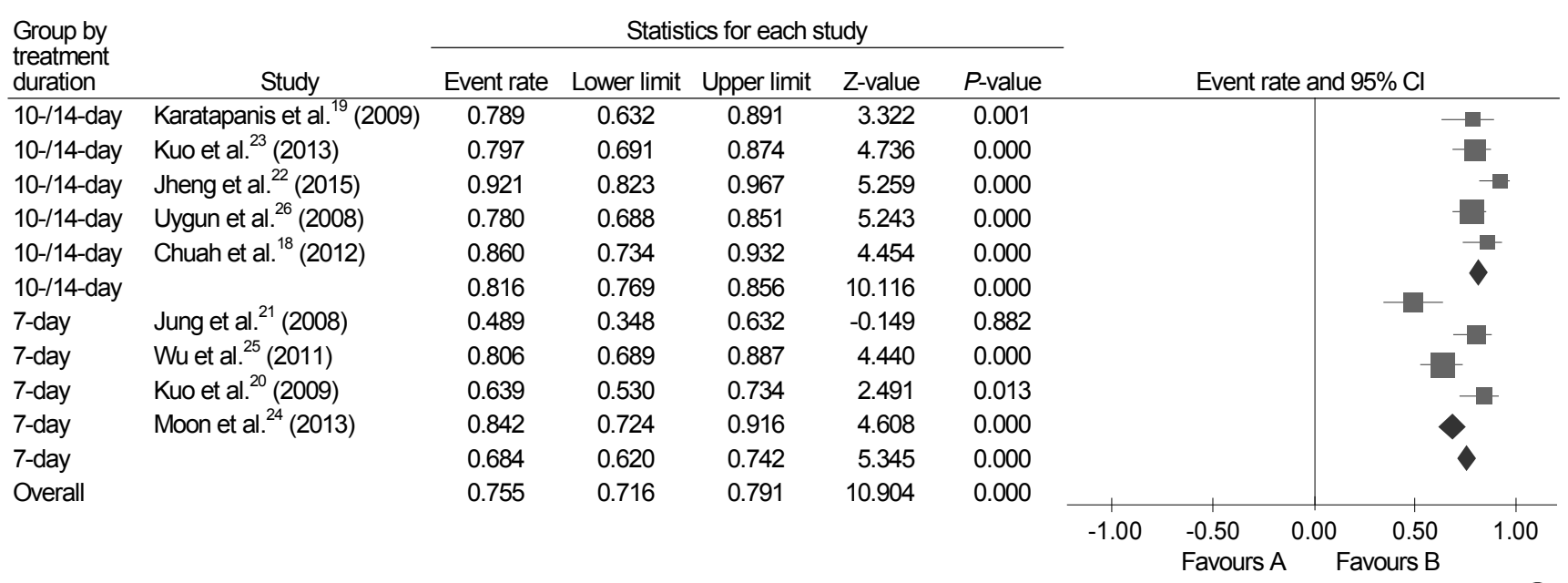

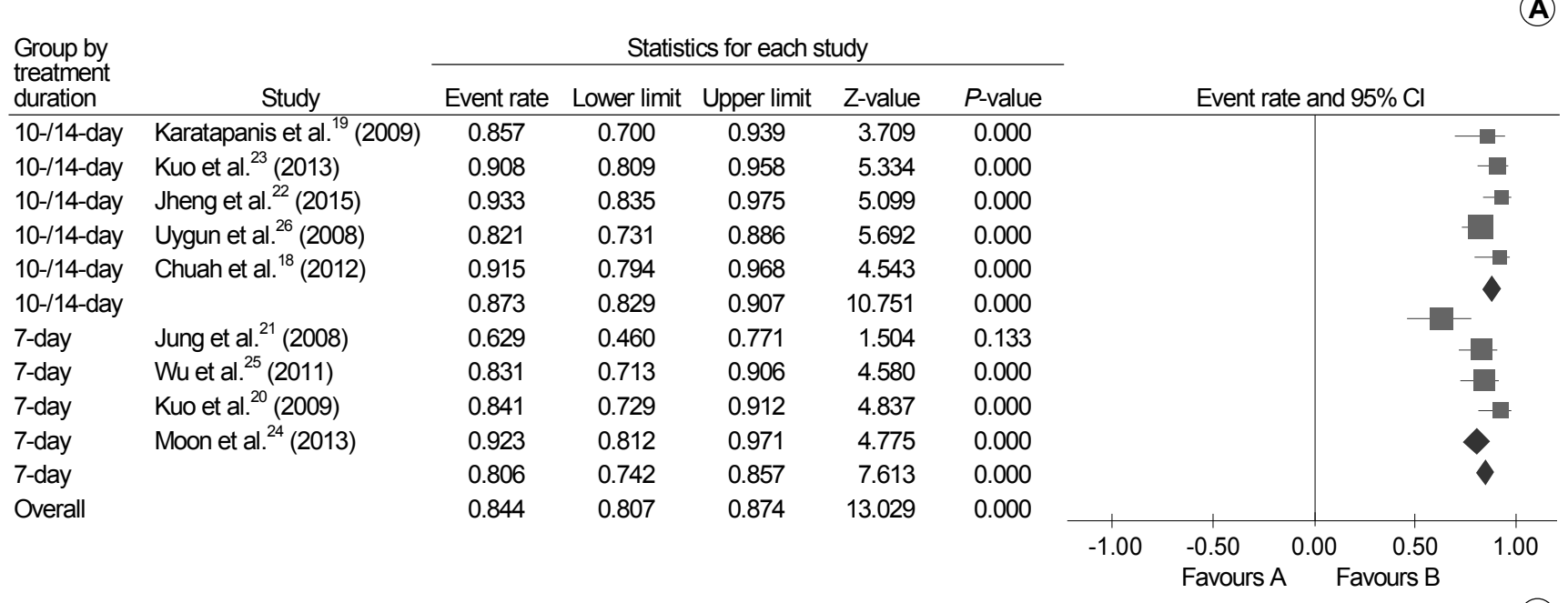

(B)

Fig. 3. Forest plot of successful eradication rates of bismuth quadruple therapy after failure of standard triple therapy. (A) Intention-to-treat analysis and (B) per-protocol analysis. 
floxacin triple therapy after failure of first-line standard triple therapy $(\mathrm{n}=8))^{18-21,27-30}$ and 4) bismuth quadruple therapy versus levofloxacin triple therapy after failure of first-line standard triple therapy $(n=4){ }^{18-21}$

\section{Risk of bias in individual studies}

Fig. 2 shows the quality assessment of the studies included in the meta-analysis. There was no high risk of bias in the 16 studies. Blinding of participants, investigators, and outcome assessors were adequate in all studies. Incomplete outcome data and selective reporting were unclear only in one study. However, allocation concealment was adequate only in four studies, and random sequence in 11 studies.

\section{Bismuth quadruple therapy after failure of standard triple therapy}

A total of 572 patients received bismuth quadruple therapy after failure of first-line standard triple therapy in nine studies, and the eradication was successful in 441 patients. ${ }^{18-26}$ The pooled eradication rates were $75.5 \%$ (95\% CI, 71.6 79.1\%; $\left.I^{2}=78.25 \%\right)$ in ITT analysis and 84.4\% (95\% CI, 80.7 87.4\%; $I^{2}=61.8 \%$ ) in PP analysis (Fig. 3). In the subgroup analyses, the ITT pooled eradication rates were $68.4 \%$ (95\% CI, 53.0 73.4\%; $\left.I^{2}=34.5 \%\right)$ after 7-day therapy and $81.6 \%$ (95\% CI, 76.9 85.6\%; $\left.I^{2}=83.9 \%\right)$ after $10-14$-day therapy $(P<0.001)$. In the PP analysis, successful eradication rates were $80.6 \%$ (95\% CI, 74.2 85.7\%; $\left.I^{2}=29.6 \%\right)$ after 7-day therapy and $87.3 \%(95 \% \mathrm{CI}$, 82.9 90.7\%; $\left.I^{2}=73.8 \%\right)$ after 10-14-day therapy $(P<0.001)$.

In the three RCTs that compared 7-day versus 14-day bismuth quadruple therapy after failure of first-line standard triple therapy, 595 patients were included: of whom 295 were treated with 7-day therapy and 300 were treated with 14-day therapy. ${ }^{49-51}$ In the meta-analysis, the eradication rates were significantly higher with 14-day therapy than 7-day therapy by $9 \%$ point $95 \%$ CI, $2 \sim 15 \%$; $\left.I^{2}=61 \%\right)$ in ITT analysis and $12 \%$ point $(95 \%$ CI, 1 23\%; $\left.I^{2}=24 \%\right)$ in PP analysis (Fig. 4).

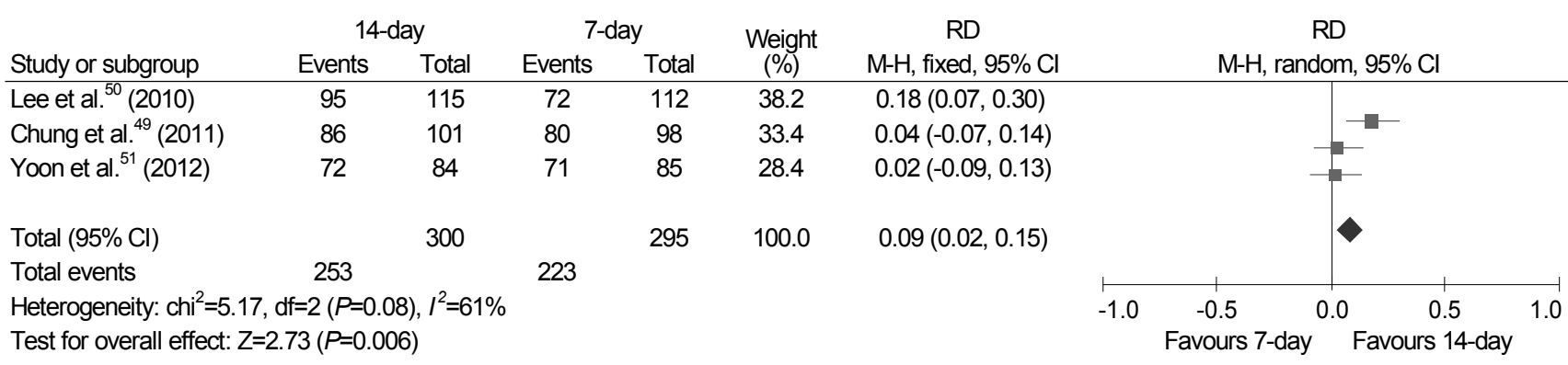

(A)

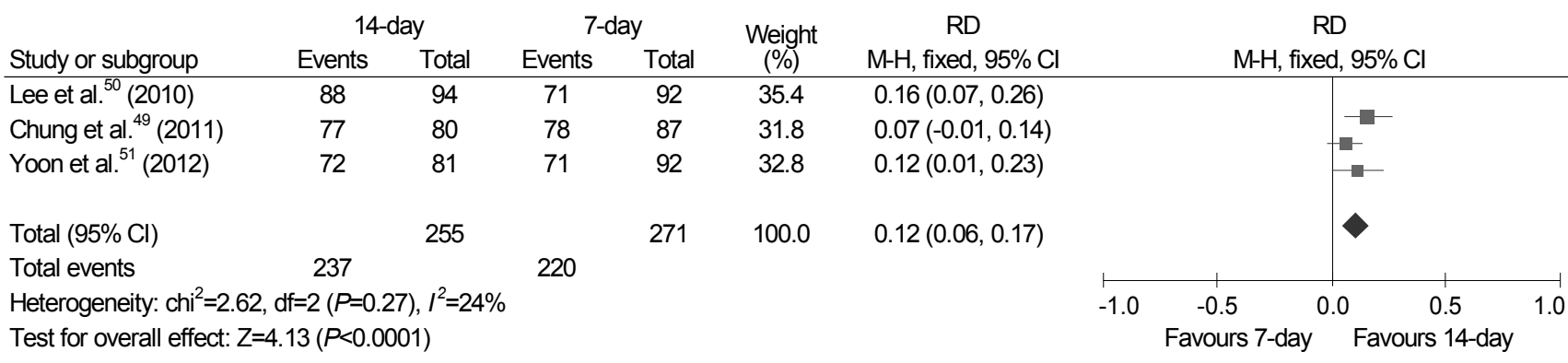

Fig. 4. Forest plot of successful eradication rates comparing 7-day and 14-day bismuth quadruple therapy after failure of standard triple therapy. (A) Intention-to-treat analysis and (B) per-protocol analysis. RD, risk difference; $\mathrm{M}-\mathrm{H}$, Mantel-Haenszel test. 


\section{Levofloxacin triple therapy after failure of standard triple therapy}

Levofloxacin triple therapy after failure of first-line standard triple therapy was administered to 433 patients in eight studies and was successful in 325 patients. ${ }^{18-21,27-30}$ The ITT and PP pooled eradication rates were $73.3 \%(95 \% \mathrm{CI}$, 68.4 77.3\%; $\left.I^{2}=71.9 \%\right)$ and $76.4 \%(95 \%$ CI, 71.7 80.6\%; $I^{2}=70.5 \%$ ), respectively (Fig. 5). The subgroup analyses showed that the eradication rate of 10-14-day therapy was significantly higher than 7-day therapy in the ITT analysis (78.5\%; $95 \%$ CI, $71.9 \sim 84.0 \% ; I^{2}=78.3 \%$ vs. $69.1 \% ; 95 \%$ CI, 62.6 74.9\%; $I^{2}=55.0 \% ; P=0.036$ ) but not in the PP analysis (81.3\%; $95 \%$ CI, $74.3 \sim 86.7 \% ; I^{2}=77.0 \%$ vs. $73.2 \% ; 95 \%$ CI, 66.6 78.9\%; $I^{2}=60.1 \% ; P=0.076$ ).

In a factorial RCT that was included in the systematic review, the authors compared 7-day versus 10-day therapy and levofloxacin $500 \mathrm{mg}$ once versus twice daily in the levofloxacin triple therapy as a rescue after failure of first-line PPI, clarithromycin, and either amoxicillin or metronidazole. ${ }^{48}$ In the results, 10-day therapy showed a higher ITT eradication rate of $87.5 \%$ (70/80) than 7-day therapy of $67.5 \%(54 / 80)(P<0.005)$, while there was no difference in the eradiation rates between levofloxacin $500 \mathrm{mg}$ once versus twice daily.

\section{Bismuth quadruple therapy vs. levofloxacin triple therapy after failure of standard triple therapy}

Bismuth quadruple therapy and levofloxacin triple therapy were directly compared as second-line regimens after

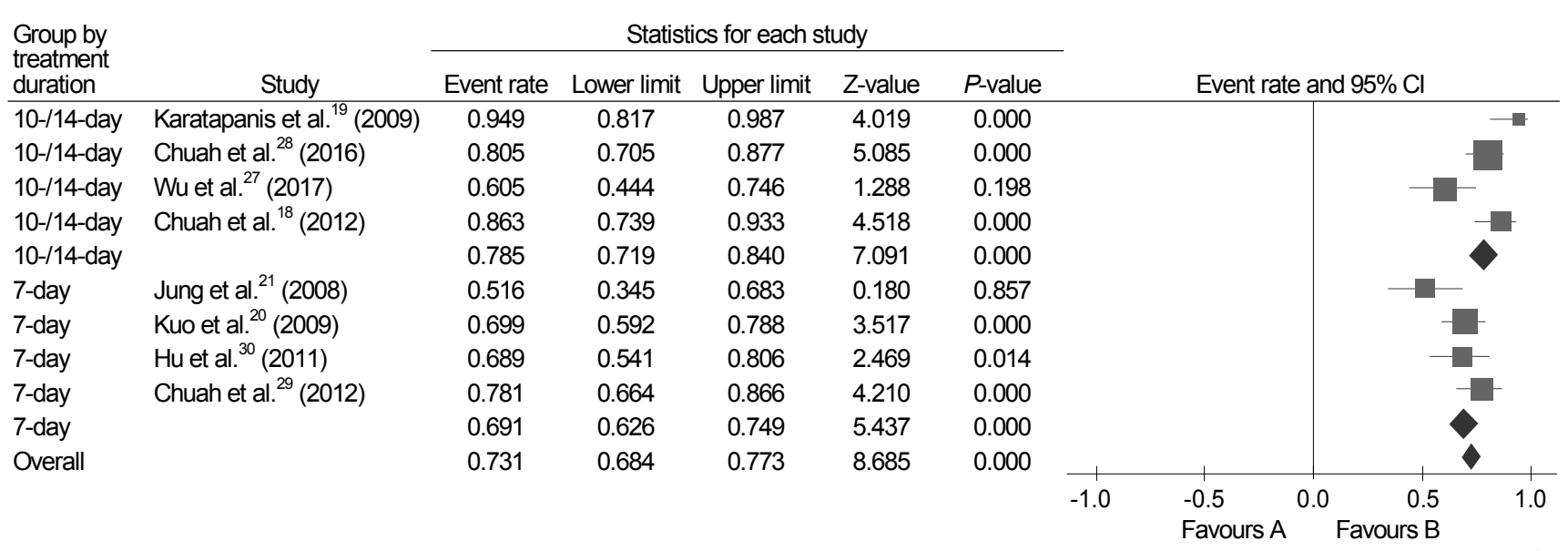

Group by

treatment

duration

Statistics for each study

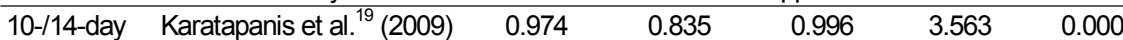

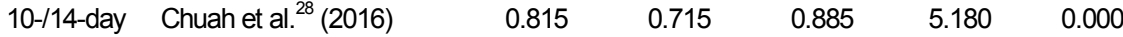

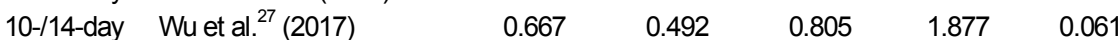

10-/14-day Chuah et al. ${ }^{18}(2012) \quad 0.936 \quad 0.820 \quad 0.979 \quad 4.501 \quad 0.000$

10-/14-day

7-day

7-day

7-day

7-day

7-day

0.813

Jung et al. ${ }^{21}$ (2008)

0.533

Kuo et al. ${ }^{20}$ (2009)

Hu et al. ${ }^{30}$ (2011)

0.753

0.743

0.867

0.358

0.701

$7.090 \quad 0.000$

$0.365 \quad 0.715$

$\begin{array}{llll}0.645 & 0.837 & 4.222 & 0.000\end{array}$

$0.756 \quad 0.603$

0.863

3.111

0.803

0.685

0.732

0.666

0.885

4.368

0.789

Overall

0.764

0.717

0.806

6.260

0.002

0.000

0.000

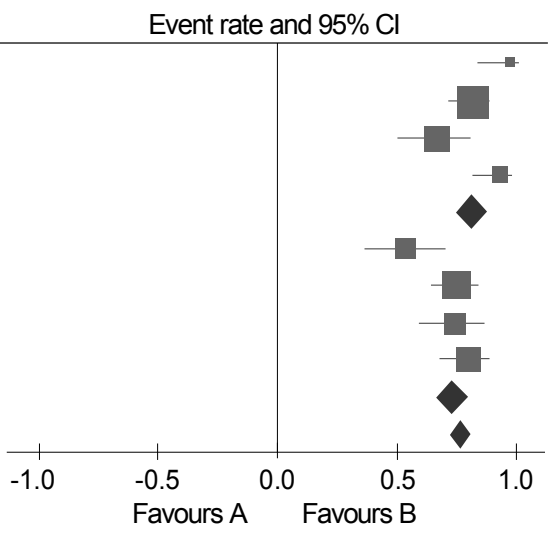

(B)

Fig. 5. Forest plot of successful eradication rates of levofloxacin triple therapy after failure of standard triple therapy. (A) Intention-to-treat analysis and (B) per-protocol analysis. 
failure of first-line standard triple therapy in 420 patients in four trials: 216 patients received bismuth quadruple therapy and 204 patients received levofloxacin triple therapy (Fig. 6). ${ }^{18-21}$ There was no significant difference in the eradication rates both in ITT and PP analyses. In detail, there was a tendency of favoring levofloxacin triple therapy over bismuth quadruple therapy by $6 \%$ point (95\% CI, $-2 \%$ to $\left.14 \% ; I^{2}=0 \% ; P=0.160\right)$ in the ITT analysis, but a tendency of favoring bismuth quadruple therapy over levofloxacin triple therapy by $2 \%$ point $(95 \%$ CI, $-5 \%$ to $10 \% ; I^{2}=54 \% ; P=0.580$ ).

\section{DISCUSSION}

In this study, we systematically reviewed salvage therapies after failure of previous $H$. pylori eradication treatment and found that the regimens were highly heterogeneous. Among them, evidences were relatively sufficient for 14-day bismuth quadruple therapy and 10-day levofloxacin triple therapy after failure of first-line standard triple therapy. On the contrary, there was no study that evaluated salvage regimens after failure of bismuth or non-bismuth quadruple therapy.

In our systematic review, studies were sufficiently robust to support second-line salvage regimen after failure of standard triple therapy. Nine and eight RCTs evaluated bismuth quadruple therapy and levofloxacin triple therapy, respectively, and four of them directly compared the two treatments. The pooled eradication rates of the regimens were comparable to each other, and particularly, there was no significant difference in the successful eradication rates between the two regimens. In previous meta-analyses, 10-day levofloxacin triple therapy demonstrated higher eradiation rate than 7-day bismuth quadruple therapy. ${ }^{10,11}$ It seems that the two regimens showed similar efficacy because they were administered for the same duration at each study in our analysis (7, 10, or 14 days each). However, before applying these results to our practice, it is necessary to consider the pattern of $H$. pylori antibiotic resistance in Korea. In a recent nationwide study, the prevalence of levofloxacin-resistant H. pylori strain was 37.0\%. The efficacy

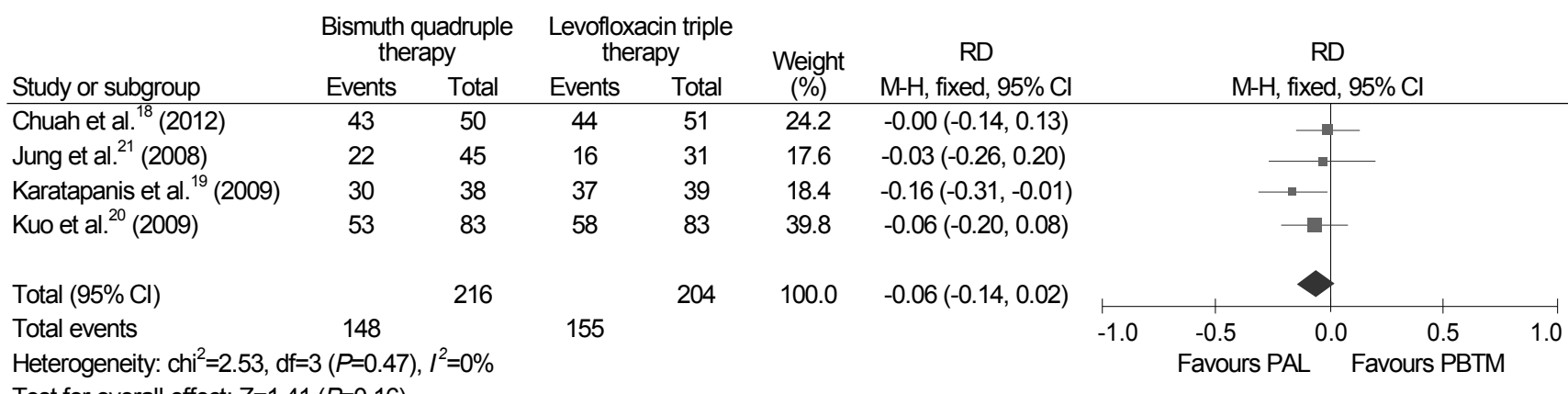

Test for overall effect: $Z=1.41(P=0.16)$

\begin{tabular}{|c|c|c|c|c|c|c|c|c|c|}
\hline \multirow[b]{2}{*}{ Study or subgroup } & \multicolumn{2}{|c|}{$\begin{array}{l}\text { Bismuth quadruple } \\
\text { therapy }\end{array}$} & \multicolumn{2}{|c|}{$\begin{array}{l}\text { Levofloxacin triple } \\
\text { therapy }\end{array}$} & \multirow{2}{*}{$\begin{array}{c}\text { Weight } \\
(\%)\end{array}$} & \multirow{2}{*}{$\begin{array}{c}R D \\
M-H, \text { fixed, } 95 \% \mathrm{Cl}\end{array}$} & \multirow{2}{*}{\multicolumn{2}{|c|}{$\begin{array}{c}\mathrm{RD} \\
\mathrm{M}-\mathrm{H}, \text { fixed, } 95 \% \mathrm{Cl}\end{array}$}} & \\
\hline & Events & Total & Events & Total & & & & & \\
\hline Chuah et al. $^{18}(2012)$ & 43 & 47 & 44 & 47 & 25.4 & $-0.02(-0.13,0.08)$ & & $=$ & \\
\hline Jung et al. ${ }^{21}$ (2008) & 22 & 35 & 16 & 30 & 17.5 & $0.10(-0.14,0.34)$ & & $=$ & \\
\hline Karatapanis et al. ${ }^{19}(2009)$ & 30 & 35 & 37 & 38 & 19.7 & $-0.12(-0.24,0.01)$ & & $\Rightarrow$ & \\
\hline Kuo et al. ${ }^{20}(2009)$ & 53 & 63 & 58 & 77 & 37.5 & $0.09(-0.04,0.22)$ & & $=-$ & \\
\hline Total $(95 \% \mathrm{Cl})$ & & 180 & & 192 & 100.0 & $0.22(-0.05,0.10)$ & & & \\
\hline Total events & 148 & & 155 & & & & -1.0 & $\begin{array}{ll}-0.5 & 0.0\end{array}$ & 0.5 \\
\hline Heterogeneity: $\mathrm{chi}^{2}=6.52, \mathrm{df}$ & $(P=0.09$ & $54 \%$ & & & & & & Favours PAL Favours & S PBTM \\
\hline
\end{tabular}

Test for overall effect: $Z=0.56(P=0.58)$

Fig. 6. Forest plot of successful eradication rate comparing bismuth quadruple therapy(PBTM) and levofloxacin triple therapy (PAL) after failure standard triple therapy. (A) Intention-to-treat analysis and (B) per-protocol analysis. RD, risk difference; M-H, Mantel-Haenszel test. 
of levofloxacin triple therapy is substantially compromised for $H$. pylori with levofloxacin resistance. ${ }^{18}$ Therefore, in Korea, bismuth quadruple therapy, rather than levofloxacin triple therapy, can be recommended as a second-line treatment after failure of standard triple therapy. This is consistent with the previous Korean guidelines. ${ }^{2}$ However, this guideline lacked the recommendation on the duration of this regimen. In our analysis, 10-/14-day treatment showed $>80 \%$ ITT and $>85 \%$ PP eradication rates in the subgroup analysis, and 14-day treatment showed significantly higher eradication rates than 7-day treatment in the direct comparison. In the abovementioned study, the prevalence of metronidazole resistance was also high as $29.5 \%$ in Korea. ${ }^{5}$ Increasing duration and dose of metronidazole can overcome the metronidazole resistance. ${ }^{54}$ Therefore, 14-day bismuth quadruple therapy would be most suitable option for the salvage treatment after failure of standard triple therapy in Korea.

The evidence regarding salvage regimen after failure of non-bismuth or bismuth quadruple therapy was very weak in our study because no RCT was identified in the literature review. Similarly, recent guidelines provided recommendations based on the meta-analyses of cohort studies. $^{7-9}$ Levofloxacin triple therapy showed 81\% (95\% CI, 71 91\%) eradication rate after failure of non-bismuth quadruple therapy in a meta-analysis of 86 patients in five observational studies. ${ }^{14}$ Meanwhile, bismuth quadruple therapy presented $85 \%$ (95\% CI, 63 100\%) eradication rate after failure of non-bismuth quadruple therapy in another meta-analysis of two studies of unknown number of patients. ${ }^{7}$ Thus, bismuth quadruple therapy may be recommended as a salvage regimen after failure of non-bismuth quadruple therapy in Korea because of high levofloxacin resistance rate. Nevertheless, levofloxacin triple therapy may be considered after failure of bismuth quadruple therapy. A meta-analysis of 501 patients in five cohort studies conducted in Maastricht $\mathrm{V}$ report showed $70.0 \%$ (95\% CI, 62.4 76.6\%) eradication rate of third-line levofloxacin triple therapy. ${ }^{7}$ In a recent Korean retrospective cohort study, the eradication rate of third-line levofloxacin triple therapy was 56.9\% $(62 / 109) .{ }^{55}$ Taken together with these studies and guidelines, our study emphasizes the urgent need for the stud- ies regarding salvage regimens after failure of non-bismuth or bismuth quadruple therapy. Potential new salvage regimens may include levofloxacin-bismuth therapy (PPI, amoxicillin, levofloxacin, bismuth) that is expected to overcome levofloxacin resistance using bismuth. ${ }^{27,36}$

There are several limitation in our study. First, we included RCTs only, but this strategy may not appropriate to evaluate salvage regimens after failure of non-bismuth quadruple therapy because this regimen was introduced more relatively than the standard triple therapy. Second, the studies included in the review were highly heterogeneous and the number of studies included in the meta-analysis was small that publication bias was not assessed. Third, only five of 16 studies that were included in the meta-analysis were conducted in Korea, which compromised applicability of study results to Korean patients. The efficacy of $H$. pylori eradication can be affected by regional differences in antibiotic resistance. So, although levofloxacin triple therapy showed similar efficacy to bismuth quadruple therapy in the meta-analysis, this regimen may not be recommended as a salvage regimen after failure of standard triple therapy in Korea because of high $H$. pylori resistance rate to levofloxacin.

In conclusion, the present systematic review showed that the current studies regarding salvage regimens were highly heterogeneous. Bismuth quadruple therapy and levofloxacin triple therapy may be reliable option after failure of standard triple therapy, but regional profile in antibiotics resistance should be considered. Further studies are needed to evaluate salvage regimens after failure of non-bismuth or bismuth quadruple therapy.

\section{ACKNOWLEDGEMENT}

We would like to express our deep gratitude to Mi-young Choi, $\mathrm{PhD}$ of National Evidence based Healthcare Collaborating Agency who performed initial literature search for systematic review, Ein Soon Shin, PhD \& MPH, Research Head of the Research Agency for Clinical Practice Guidelines of Korean Academy of Medical Sciences for the Meta-Analysis Workshop. 


\section{CONFLICTS OF INTEREST}

No potential conflict of interest relevant to this article was reported.

\section{ORCID}

\begin{tabular}{|c|c|}
\hline yo-Joon Yang & (e) \\
\hline ye-Kyung Jung & (1D) https://orcid.org/0000-0002-6653-5214 \\
\hline Sang & (D) https://orcid.c \\
\hline Chan Jee & 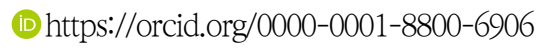 \\
\hline $\operatorname{ark}$ & 0 \\
\hline in Shin & (i) https://orcid.org/0000-0003-2265 \\
\hline g Eun Kim & (D) https://orcid.c \\
\hline $\mathrm{m}$ & (D) https://orcid.org/0000-00 \\
\hline & (D) https://orcid.org/0000-0002 \\
\hline Youn Nam & (D) https://orcid.org/0000-0002- \\
\hline & \\
\hline e Myung Park & (1) https://orcid.org/0000-0002- \\
\hline Ju Choi & $g / 0000-0002-$ \\
\hline & 1 \\
\hline & /0000-0002 \\
\hline
\end{tabular}

\section{REFERENCES}

1. Lee JH, Choi KD, Jung HY, et al. Seroprevalence of Helicobacter pylori in Korea: a multicenter, nationwide study conducted in 2015 and 2016. Helicobacter 2018;23:e12463.

2. Kim SG, Jung HK, Lee HL, et al. Guidelines for the diagnosis and treatment of Helicobacter pylori infection in Korea, 2013 revised edition. J Gastroenterol Hepatol 2014;29:1371-1386.

3. Choi IJ, Kim CG, Lee JY, et al. Family history of gastric cancer and Helicobacter pylori treatment. N Engl J Med 2020;382: 427-436.

4. Choi IJ, Kook MC, Kim YI, et al. Helicobacter pylori therapy for the prevention of metachronous gastric cancer. N Engl J Med 2018;378:1085-1095.

5. Lee JH, Ahn JY, Choi KD, et al. Nationwide antibiotic resistance mapping of Helicobacter pylori in Korea: a prospective multicenter study. Helicobacter 2019;24:e12592.

6. Kim BJ, Lee H, Lee YC, et al. Ten-day concomitant, 10-day sequential, and 7-day triple therapy as first-line treatment for Helicobacter pylori infection: a nationwide randomized trial in Korea. Gut Liver 2019;13:531-540.

7. Malfertheiner P, Megraud F, O'Morain CA, et al. Management of Helicobacter pylori infection-the Maastricht V/Florence consensus report. Gut 2017;66:6-30.
8. Chey WD, Leontiadis GI, Howden CW, Moss SF. ACG clinical guideline: treatment of Helicobacter pylori infection. Am J Gastroenterol 2017;112:212-239.

9. Fallone CA, Chiba N, van Zanten SV, et al. The Toronto consensus for the treatment of Helicobacter pylori infection in adults. Gastroenterology 2016;151:51-69.e14.

10. Gisbert JP, Morena F. Systematic review and meta-analysis: levofloxacin-based rescue regimens after Helicobacter pylori treatment failure. Aliment Pharmacol Ther 2006;23:35-44.

11. Saad RJ, Schoenfeld P, Kim HM, Chey WD. Levofloxacin-based triple therapy versus bismuth-based quadruple therapy for persistent Helicobacter pylori infection: a meta-analysis. Am J Gastroenterol 2006;101:488-496.

12. Gisbert JP; H. pylori Study Group of the Spanish Gastroenterology Association. Letter: third-line rescue therapy with levofloxacin after failure of two treatments to eradicate Helicobacter pylori infection. Aliment Pharmacol Ther 2012; 35:1484-1485; author reply 1486.

13. Gisbert JP, Calvet X. Review article: rifabutin in the treatment of refractory Helicobacter pylori infection. Aliment Pharmacol Ther 2012;35:209-221.

14. Marin AC, McNicholl AG, Gisbert JP. A review of rescue regimens after clarithromycin-containing triple therapy failure (for Helicobacter pylori eradication). Expert Opin Pharmacother 2013;14:843-861.

15. Muñoz N, Sánchez-Delgado J, Baylina M, et al. Systematic review, meta-analysis, and meta-regression: successful second-line treatment for Helicobacter pylori. Helicobacter 2018; 23:e12488.

16. Moher D, Liberati A, Tetzlaff J, Altman DG; PRISMA Group. Preferred reporting items for systematic reviews and meta-analyses: the PRISMA statement. PLoS Med 2009;6:e1000097.

17. Higgins JP, Altman DG, Gøtzsche PC, et al. The Cochrane Collaboration's tool for assessing risk of bias in randomised trials. BMJ 2011;343:d5928.

18. Chuah SK, Tai WC, Hsu PI, et al. The efficacy of second-line anti-Helicobacter pylori therapy using an extended 14-day levofloxacin/amoxicillin/proton-pump inhibitor treatment--a pilot study. Helicobacter 2012;17:374-381.

19. Karatapanis S, Skorda L, Georgopoulos S, et al. Levofloxacinbased triple therapy versus bismuth-based quadruple therapy as a second line treatment for the eradication of $H$. pylori infection. Ann Gastroenterol 2009;22:263-267.

20. Kuo CH, Hu HM, Kuo FC, et al. Efficacy of levofloxacin-based rescue therapy for Helicobacter pylori infection after standard triple therapy: a randomized controlled trial. J Antimicrob Chemother 2009;63:1017-1024.

21. Jung HS, Shim KN, Baik SJ, et al. Efficacy of levofloxacin-based triple therapy as second-line Helicobacter pylori eradication. Korean J Gastroenterol 2008;51:285-290.

22. Jheng GH, Wu IC, Shih HY, et al. Comparison of second-line quadruple therapies with or without bismuth for Helicobacter pylori infection. Biomed Res Int 2015;2015:163960.

23. Kuo CH, Hsu PI, Kuo FC, et al. Comparison of 10 day bismuth 
quadruple therapy with high-dose metronidazole or levofloxacin for second-line Helicobacter pylori therapy: a randomized controlled trial. J Antimicrob Chemother 2013;68: 222-228.

24. Moon JY, Kim GH, You HS, et al. Levofloxacin, metronidazole, and lansoprazole triple therapy compared to quadruple therapy as a second-line treatment of Helicobacter pylori infection in Korea. Gut Liver 2013;7:406-410.

25. Wu DC, Hsu PI, Tseng HH, et al. Helicobacter pylori infection: a randomized, controlled study comparing 2 rescue therapies after failure of standard triple therapies. Medicine (Baltimore) 2011;90:180-185.

26. Uygun A, Ozel AM, Yildiz O, et al. Comparison of three different second-line quadruple therapies including bismuth subcitrate in Turkish patients with non-ulcer dyspepsia who failed to eradicate Helicobacter pylori with a 14-day standard first-line therapy. J Gastroenterol Hepatol 2008;23:42-45.

27. Wu TS, Hsu PI, Kuo CH, et al. Comparison of 10-day levofloxacin bismuth-based quadruple therapy and levofloxacinbased triple therapy for Helicobacter pylori. J Dig Dis 2017;18: 537-542.

28. Chuah SK, Liang $\mathrm{CM}$, Lee $\mathrm{CH}$, et al. A randomized control trial comparing 2 levofloxacin-containing second-line therapies for Helicobacter pylori eradication. Medicine (Baltimore) 2016;95: e3586.

29. Chuah SK, Hsu PI, Chang KC, et al. Randomized comparison of two non-bismuth-containing second-line rescue therapies for Helicobacter pylori. Helicobacter 2012;17:216-223.

30. Hu TH, Chuah SK, Hsu PI, et al. Randomized comparison of two nonbismuth-containing rescue therapies for Helicobacter pylori. Am J Med Sci 2011;342:177-181.

31. Calhan T, Kahraman R, Sahin A, et al. Efficacy of two levofloxacin-containing second-line therapies for Helicobacter pylori: a pilot study. Helicobacter 2013;18:378-383.

32. Ueki N, Miyake K, Kusunoki M, et al. Impact of quadruple regimen of clarithromycin added to metronidazole-containing triple therapy against Helicobacter pylori infection following clarithromycin-containing triple-therapy failure. Helicobacter 2009;14:91-99.

33. Liou JM, Bair MJ, Chen CC, et al. Levofloxacin sequential therapy vs levofloxacin triple therapy in the second-line treatment of Helicobacter pylori: a randomized trial. Am J Gastroenterol 2016;111:381-387.

34. Yang JC, Lin CJ, Wang HL, et al. High-dose dual therapy is superior to standard first-line or rescue therapy for Helicobacter $p y-$ lori infection. Clin Gastroenterol Hepatol 2015;13:895-905.e5.

35. Mansour-Ghanaei F, Joukar F, Naghipour MR, Forouhari A, Saadat SM. Seven-day quintuple regimen as a rescue therapy for Helicobacter pylori eradication. World J Gastroenterol 2015; 21:661-666.

36. Cao Z, Chen Q, Zhang W, et al. Fourteen-day optimized levofloxacin-based therapy versus classical quadruple therapy for Helicobacter pylori treatment failures: a randomized clinical trial. Scand J Gastroenterol 2015;50:1185-1190.
37. Munteanu D, Etzion O, Ben-Yakov G, et al. Efficacy and safety of sequential versus quadruple therapy as second-line treatment for Helicobacter pylori infection-a randomized controlled trial. PLoS One 2017;12:e0183302.

38. Gu LY, Lin WW, Lu H, Chen XY, Ge ZZ, Li XB. Quadruple therapy with medications containing either rufloxacin or furazolidone as a rescue regimen in the treatment of Helicobacter pylori-infected dyspepsia patients: a randomized pilot study. Helicobacter 2011;16:284-288.

39. Minakari M, Davarpanah Jazi AH, Shavakhi A, Moghareabed N, Fatahi F. A randomized controlled trial: efficacy and safety of azithromycin, ofloxacin, bismuth, and omeprazole compared with amoxicillin, clarithromycin, bismuth, and omeprazole as second-line therapy in patients with Helicobacter pylori infection. Helicobacter 2010;15:154-159.

40. Bago J, Pevec B, Tomić M, Marusić M, Bakula V, Bago P. Second-line treatment for Helicobacter pylori infection based on moxifloxacin triple therapy: a randomized controlled trial. Wien Klin Wochenschr 2009;121:47-52.

41. Sanches B, Coelho L, Moretzsohn L, Vieira G Jr. Failure of Helicobacter pylori treatment after regimes containing clarithromycin: new practical therapeutic options. Helicobacter 2008;13:572-576.

42. Ierardi E, Giangaspero A, Losurdo G, et al. Quadruple rescue therapy after first and second line failure for Helicobacter $p y^{-}$ lori treatment: comparison between two tetracycline-based regimens. J Gastrointestin Liver Dis 2014;23:367-370.

43. Chen Q, Zhang W, Fu Q, et al. Rescue therapy for Helicobacter pylori eradication: a randomized non-inferiority trial of amoxicillin or tetracycline in bismuth quadruple therapy. Am J Gastroenterol 2016;111:1736-1742.

44. Mori H, Suzuki H, Matsuzaki J, et al. Efficacy of 10-day sitafloxacin-containing third-line rescue therapies for Helicobacter pylori strains containing the gyrA mutation. Helicobacter 2016; 21:286-294.

45. Murakami K, Furuta T, Ando T, et al. Multi-center randomized controlled study to establish the standard third-line regimen for Helicobacter pylori eradication in Japan. J Gastroenterol 2013; 48:1128-1135.

46. Nishizawa T, Suzuki H, Nakagawa I, Iwasaki E, Masaoka T, Hibi T. Gatifloxacin-based triple therapy as a third-line regimen for Helicobacter pylori eradication. J Gastroenterol Hepatol 2008; 23 Suppl 2:S167-S170.

47. Mori H, Suzuki H, Matsuzaki J, et al. Rifabutin-based 10-day and 14-day triple therapy as a third-line and fourth-line regimen for Helicobacter pylori eradication: a pilot study. United European Gastroenterol J 2016;4:380-387.

48. Di Caro S, Franceschi F, Mariani A, et al. Second-line levofloxacin-based triple schemes for Helicobacter pylori eradication. Dig Liver Dis 2009;41:480-485.

49. Chung JW, Lee JH, Jung HY, et al. Second-line Helicobacter pylori eradication: a randomized comparison of 1-week or 2-week bismuth-containing quadruple therapy. Helicobacter 2011;16: 289-294. 
50. Lee BH, Kim N, Hwang TJ, et al. Bismuth-containing quadruple therapy as second-line treatment for Helicobacter pylori infection: effect of treatment duration and antibiotic resistance on the eradication rate in Korea. Helicobacter 2010;15:38-45.

51. Yoon JH, Baik GH, Kim YS, et al. Comparison of the eradication rate between 1- and 2-week bismuth-containing quadruple rescue therapies for Helicobacter pylori eradication. Gut Liver 2012;6:434-439.

52. Lim HC, Lee YJ, An B, Lee SW, Lee YC, Moon BS. Rifabutin-based high-dose proton-pump inhibitor and amoxicillin triple regimen as the rescue treatment for Helicobacter pylori. Helico- bacter 2014;19:455-461.

53. Kuo CH, Wang SS, Hsu WH, et al. Rabeprazole can overcome the impact of CYP2C19 polymorphism on quadruple therapy. Helicobacter 2010;15:265-272.

54. Graham DY, Lee YC, Wu MS. Rational Helicobacter pylori therapy: evidence-based medicine rather than medicine-based evidence. Clin Gastroenterol Hepatol 2014;12:177-186.e3; discussion e12-e13.

55. Lim JH, Kim SG, Song JH, et al. Efficacy of levofloxacin-based third-line therapy for the eradication of Helicobacter pylori in peptic ulcer disease. Gut Liver 2017;11:226-231. 